\title{
Masks and Maidens: Women and the Sanctuary of Artemis Orthia Toryn Suddaby
}

This paper explores the archaeological finds at the site of Artemis Orthia in Sparta through a gender-based framework. It chronicles the history of the site from the 6th century BCE to modern excavations and critically evaluates the subtle biases of recent scholarship on the artefacts found there, including bronze dedications, the Orthia masks, and an architectural votive. This research aims to question established perceptions of Sparta as unique within Greece and scholarly biases against Laconian art as r̃backwardsò by focusing on the context of the site and looking beyond the infamous literary flogging ritual to ask how women in particular fit into the mythology and archaeology. Utilizing a gender-based lens opens new possibilities and exposes modern preconceptions about gender in the ancient world, uniting seemingly contradictory elements.

After excavations in the early $20^{\text {th }}$ century, scholars have studied material from the site of Artemis Orthia at Sparta extensively. Archaeologists recovered hundreds of thousands of objects from the site. Some of these objects are lead, bronze, terracotta, ivory, or bone and depict animals, deities, wreaths, and human figures. The Roman theatre provides a clue as to whether the sanctuary matched its literary fame, but other than the infamous flogging ritual, the practices and people involved with the site in ancient times remains a mystery. I propose that the excavation of the sanctuary of Artemis Orthia could benefit from a gender-based theoretical framework in order to understand who may have used the site and why.

The sanctuary of Artemis Orthia is located at Sparta in the Peloponnese. The site is on the south bank of the Eurotas River and dates back to an altar from the Geometric period. After damage from a flood around the beginning of the $6^{\text {th }}$ century BCE, the site was raised above water level with a blanket of sand that sealed off the artefacts below. ${ }^{1}$ During this time, the site was reorganized. The new Archaic temple was enlarged from the Geometric with a porch and cella, and the temenos was expanded as well. ${ }^{2}$ Artefacts above the sand are generally less well preserved than objects sealed beneath the sand, partially due to Laconian soil being poor for preservation. ${ }^{3}$ The $3^{\text {rd }}$ century BCE Roman theatre on top of the site provides a good terminus ante quem, or the ñime before whichò the objects under the layer would have been deposited, as well as helps to keep the objects beneath intact. All that remains of the architecture aside from the theatre is the altar and the foundation of the temple. ${ }^{4}$

The British School of Athens, led by R.M. Dawkins, excavated the sanctuary as well as many other sites around Laconia. The sanctuary of Artemis Orthia was one of the larger and more expensive operations. The team worked in three main phases around Laconia: from 1904-1910, 1924-1927, and from 1973 until the present day. Due to the First World War, there was only a single publication from the excavations during Phase One. Excavations are not currently in

\footnotetext{
${ }^{1}$ Margaret E. Pinney, "Votive Gifts to Artemis Orthia," The Metropolitan Museum of Art Bulletin, no. 6 (1925): 157. The date is from the original excavation, but this date may be too early.

${ }^{2}$ Catling, H.W, "The Work of the British School At Athens At Sparta and in Laconia," British School at Athens

Studies, (1998): 23.

3 Ibid., 20.

${ }^{4}$ Paul Cartledge, Sparta and Lakonia: A Regional History from 1300 to 362 BC, (2002): 308.
} 
progress on the sanctuary, and the majority of publications are based on material recovered during the first two phases. The stratigraphy the team used is quite praiseworthy for its time, but there are still some controversial problems that the excavation has presented. ${ }^{5}$

The first major problem with the site is the absolute dates the excavators proposed. The dates are thankfully not based on the stratigraphy of the site, but the styles of the objects the site has yielded. John Boardman criticizes the excavators in an article on the site, stating that the excavators assumed an unrealistically standard rate of deposition. Orthia is not a site of consistent habitation with many layers of destruction and rebuilding as a domestic site may contain, but rather the stratigraphy is a result of r̃haphazard sweepingsò. ${ }^{6}$ Boardman also points to a rarely-cited Laconian III cup that was found beneath the layer of sand the excavators dated to Laconian II. ${ }^{7}$ As a result of his research, Boardman proposes that the dates the excavators gave be pushed later. ${ }^{8}$ These dates are still under debate today as the excavators made little attempt to synchronize them with the standard chronology, focusing only on the site they were working on. ${ }^{9}$

The fact that the excavators did not try to synchronize their site with the established chronology might be linked to the notion that Sparta was always the exception to any other site in Greece. This bias has made scholars focus on Sparta as an isolated, independent site and they often do not make comparisons with the rest of Greece. For example, the decline of bronze dedications at Orthia conveniently becomes evidence for institutionalized Spartan austerity. ${ }^{10}$ This phenomenon, however, also occurred around Greece in a similar timeframe. Even in Sparta itself, different temples demonstrated divergent trends. During ñSpartan austerityò, bronze declined at Orthia but actually increased at the Amyklaion. ${ }^{11}$ As this is a point where evidence contradicts scholarly assumptions about Sparta, we need to consider other avenues of thought. Anthony Snodgrass proposes that this change in votives reflected a larger change in religious practice, for example. Rather than reflecting Spartan austerity and the end of Laconian bronze vessel production, the decline could mean a shift from bronze dedications to bronze funerary or domestic display objects. ${ }^{12}$ Scholars need to look at other possibilities rather than relying too heavily on literary evidence about Sparta as the exception to the rules.

The literary perception of Sparta as backwards and out of sync with the rest of Greece can lead, or mislead, scholars to look for exotic connections from Sparta to practices outside of Greece. Jane Burr Carter makes links between the cult of Artemis Orthia and a Phoenician cult dedicated to the goddess Asherah. ${ }^{13}$ The masks found at Orthia, according to Carter, closely resemble images from Near Eastern art. They have similar s-shaped designs on their cheeks and grotesque features. Carter draws a parallel between the story of Gilgamesh and Humbaba, as well as the

\footnotetext{
${ }^{5}$ H.W. Catling, ñThe Work of the British School,ò 20-21.

${ }^{6}$ John Boardman,"Artemis Orthia and Chronology," The Annual of the British School at Athens, (1963): 1.

${ }^{7}$ Ibid., 2.

${ }^{8}$ Ibid., 7.

${ }^{9}$ Konstantinos Kopanias, "Some ivories from the Geometric stratum at the sanctuary of Artemis Orthia, Sparta: interconnections between Sparta, Crete and the Orient during the late eighth century BC," British School at Athens Studies, 16 (2009): 123.

${ }^{10}$ Stephen Hodkinson, "Patterns of bronze dedications at Spartan sanctuaries, c. $650 ð 350$ BC: towards a quantified database of material and religious investment," British School at Athens Studies, (1998): 55.

11 Ibid., 57.

12 Ibid., 60.

${ }^{13}$ Jane Burr Carter, "The Masks of Ortheia," American Journal of Archaeology, 91, no. 3 (1987): 355.
} 
story of Perseus and Medusa to strengthen her claim. ${ }^{14}$ She concludes that either the Spartans had a strong affinity for this particular Phoenician cult, or the Phoenicians themselves installed their own cultic rituals. Greece definitely had contact with the highly influential Phoenicians, and it is very likely that Phoenician traders or craftsmen would have settled in Greece and brought their cultures with them. ${ }^{15}$

However, Carter may be stretching the evidence in order to fit the preconception that Sparta is somehow inherently different from the rest of Greece. While it is true that life-size wearable masks in a ritual context are rare outside of sites within Spartấ sphere of influence, it does not necessitate an exotic foreign connection. ${ }^{16}$ The Near Eastern masks Carter cites as the origins of the Orthia masks were a thousand years older than their Spartan counterparts. ${ }^{17}$ Even if the Orthia masks were the result of foreign influence, it could have easily been a local interpretation of Near Eastern forms without any ideological import attached. The presence of the masks in Sparta and the absence of them elsewhere in Greece do not necessarily need a foreign origin story. It is just as likely they were a local invention the Spartans could have used to present themselves as unique. Whether or not the masks even resemble those from the Near East can be quite subjective, just as perceptions of Laconian art in general can be.

In addition to the tendency to isolate Sparta, there appears to be a bias in scholarship towards Laconian art as a whole. Once again it seems to be connected to the image of Sparta, ñthe Spartan Mirageò as Paul Cartledge identifies it, as economically and culturally austere. ${ }^{18}$ There is arguably more of a focus on ñthe decline of Laconian artòthan on the pieces themselves, and scholars often only examine works they consider to be ñartistically significantò. ${ }^{19}$ Laconian art never seems to have reached the idealistic veristic classical or Hellenistic styles associated with perhaps the Berlin Painter or Praxiteles, that is, the perfect proportions and ñrealisticò styles modern audiences associate with Greek art. However, it is naïve to assume that these styles were the ultimate goal of Laconian artists or the result of a natural evolutionist progression of art. The notion that the lack of ñprogressò in Spartan art in particular is because of the military reforms associated with it, and is extremely short-sighted and biased.

Scholars have approached Laconian archaeology in a number of different ways, but one angle that definitely could use more exploration is a gender-based theoretical framework. Feminist theory is a relatively new field of research and has often been neglected in the past as a ñspecial interestò group. ${ }^{20}$ By scrutinizing the discourse through a feminist lens, we can begin to reveal and overcome modern biases about gender in the scholarship. Once we become aware of these biases, we can begin to understand how the cultures we study may differ from our modern constructions of gender or sexuality. We can also begin to divorce the ideals and stereotypes about women in ancient Greek literature from the realities when we inquire about who made, used, and deposited these artefacts and why.

\footnotetext{
${ }^{14}$ Carter, ñThe Masks of Ortheia,ò 360-361.

15 Ibid., 374.

${ }^{16}$ Ibid., 359.

${ }^{17}$ Ibid., 355.

${ }^{18}$ Paul Cartledge, Spartan Reflections. Berkeley and Los Angeles: University of California Press, 2001.4.

${ }^{19}$ Hodkinson, ñPatterns of Bronze,ò56.

${ }^{20}$ Shelby Brown, "Feminist Research in Archaeology: What Does It Mean? Why Is It Taking So Long?," chap. 10 in Feminist Theory and the Classics, ed. Nancy Sorkin Rabinowitz and Amy Richlin (London: Routledge, 1993). 239.
} 
A gender based study of Sparta is difficult not only because of the historically common male bias in literature but also because of how Athenian writers depict Spartans as ñthe Otherò. Spartan women become the foils for the ideal Athenian woman. Where the Athenian is modestly dressed, the Spartan displays her bare thighs. While the Athenian woman stays indoors and out of sight of strange men, the Spartan woman exercises outdoors together with men. Where an Athenian woman had no political or economic status of her own, a Spartan woman could own property. ${ }^{21}$ How much of this dichotomy is true or exaggerated is difficult to say, especially because literature on women was primarily written by and for men. The Athenian male bias is something scholars must be extremely conscious of when examining material culture; otherwise archaeologists will overlook other important details in favour of literary evidence. That being said, how can we reconcile our perceptions of Greek culture with evidence that does not match it?

An object that does not appear to fit the context is a fragment of a temple or house model found at Orthia. The fragment was locally made, but as a result of the excavation came to us without context. The excavators placed the fragment in a tray labeled ñnon-descriptò from the $7^{\text {th }}-5^{\text {th }}$ centuries, and it was originally assumed to be rubble from the mud brick foundation of the temple. R.W.V. Catling is certain by the shape of the fragment that it is part of an architectural model. The style of the model is generally unhelpful and it is not clear what kind of building it was a model of. Catling indicates that it likely had a pitched roof and was a simplified version of contemporary architecture, but whether it was a model of a specific building or not is unclear. ${ }^{22}$ Usually, scholars such as Catling refer to these models as temples or houses, but whether there was even a distinction between these two types of buildings for the ancients is not something that can be excavated with the artefact. These models were not uncommon in the rest of Greece, but what is puzzling about this artefact is why it was found at a sanctuary to Artemis Orthia rather than perhaps Hera or Athena. ${ }^{23}$

Artemis is the goddess of the wilderness, and the locations of her sanctuaries typically reflect that. Sanctuaries to Artemis appear in spaces associated with transition from civilization to nature, including forests, mountains, and shorelines. ${ }^{24}$ There are other transitions Artemis is associated with as well. One such transition is safe passage through dangerous terrain, which is why sanctuaries to Artemis are often along dangerous roads or from look-out points on mountains. ${ }^{25}$ Artemis is not limited to rural areas, however. She is even present in cities, usually in busy areas such as the agora or at intersections of roads. ${ }^{26}$ The abduction of young maidens from sanctuaries of Artemis is a common mythological trope, including in Spartan literature, due to the dangers associated with the sanctuariesôlocations. ${ }^{27}$ Finally, Artemis is associated with more abstract, personal, and emotional transitions. For example, sanctuaries of Artemis prepare young men heading into battle with rituals to transform them into soldiers. ${ }^{28}$ Likewise, Artemis is

\footnotetext{
${ }^{21}$ Michael Scott, "The Rise of Women in Ancient Greece,"History Today, November 2009, 38.

${ }^{22}$ R.W.V. Catling, "A Fragment of an Archaic Model from Artemis Orthia, Sparta," The Annual of the British School at Athens, (1994): 271-272.

${ }^{23}$ Ibid., 274.

${ }^{24}$ Susan Guettel Cole, "Landscapes of Artemis," The Classical World, no. 5 (2000): 473.

25 Ibid., 475.

${ }^{26}$ Ibid., 474.

${ }^{27}$ Ibid., 472.

${ }^{28}$ Ibid., 478.
} 
also the goddess of transitions from childhood to adulthood, including the transformation of girls into women.

If Artemis is not simply the goddess of the wilds, Catling $\hat{Q}$ confusion at a domestic model appearing at one of her sanctuaries becomes less of an obstacle. While not as immediately domestic as perhaps Athena or Hera, Artemis provided protection for girls as they became older and to women during childbirth. ${ }^{29}$ To phrase it another way, Artemis was a guide in the transitions from girl to woman and woman to mother. Perhaps because there is so little explicit evidence for this association at Orthia, it is rarely mentioned in scholarly accounts of the archaeology. Scholars may hope to avoid the pitfalls of using archaeology to illustrate the literature, but it gives the impression that the only roles girls could fulfill in this context was to dance until captured. If the architectural model is a symbol of domesticity, perhaps it is the embodiment of a hoped for outcome of a girlôs transition. On the other hand, how does the concept of ñdomesticityò mesh with literary accounts of women in communal Sparta?

Because of Spartaôs emphasis on the public rather than the private sphere, private cults were unknown in Sparta. As in other places in Greece, there were cults that were exclusively for men or women, as well as cults for both genders. ${ }^{30}$ Presumably, women in Sparta and the rest of Greece not only danced at festivals but participated in other aspects of religious life. Spartan women could dedicate their own votives, participate in races, weave clothing for their cult statues and perhaps even drive chariots in religious processions. ${ }^{31}$ What evidence for these activities at Artemis Orthia is present in the archaeology or literature?

First of all, Elinor Bevan suggests that one type of votive may be specifically a dedication on behalf of, if not from a woman. Votives normally take the form of a variety of animals, but bears are rarely if ever depicted. Bear-shaped votives appear at only five of the sixty sanctuaries Bevan studied: two of them dedicated solely to Artemis and one sanctuary including Artemis. One of these sanctuaries is that of Artemis Orthia. ${ }^{32}$ Typically, votives depict animal sacrifices, and although bears are not as common as other animals they have appeared in the literary record as sacrifices before. ${ }^{33}$ Bevan proposes that bears have a strong connection to Artemis and also resonate with mythology about motherhood. In mythology, Artemis turns her companion Kallisto into a she-bear after Kallisto bore a son. The heroine Atalanta was raised by a she-bear, according to legend. Because of this association, Bevan suggests that bear votives too had a strong association with childbirth and motherhood, like Artemis herself. ${ }^{34}$ Perhaps Bevan is overlooking other factors in favour of literary sources, but there are other objects and literary examples from the site to consider as well.

Sarah B. Pomeroy summarizes the archaeological and literary evidence about the Orthia sanctuary concisely. She cites lead figurines from the site of men and women playing musical instruments as evidence that women did indeed participate in such activities at the sanctuary. As for the literary evidence, she postulates that girls may have performed a certain dance in a

${ }^{29}$ Sarah B. Pomeroy, Spartan Women, (Oxford: Oxford University Press, 2002). 107.

${ }^{30}$ Ibid., 105.

${ }^{31}$ Ibid., 106.

${ }^{32}$ Elinor Bevan, "The Goddess Artemis, and the Dedication of Bears in Sanctuaries," The Annual of the British

School at Athens, 82 (1987): 17.

${ }^{33}$ Ibid., 18.

${ }^{34}$ Ibid., 19. 
secluded place in reference to the many myths of the abduction of young girls. Pomeroy actually brings to light that abduction could have been a metaphor for marriage and the dancing was a ritualized allusion to that. The origins of the cult were as much a mystery to the ancients as it is to us, but the primary function definitely appears to be for publically celebrating the next generation. ${ }^{35}$

Another puzzling find from the sanctuary of Artemis Orthia includes the life sized terracotta masks. As I have mentioned, these masks are not found anywhere else in Greece, with the notable exception of communities within Spartâิ sphere of influence. Their uniqueness has caused scholars to look for examples outside of Greece, as we have seen Carter explore.

However, scholars tend to ignore the domestic functions of these masks in search of origins that may not necessarily be as important or even worthy of study. Guy Dickens referred to the masks as ñold Womenò because he associated them with a literary account of a festival involving men wearing the masks of ugly old women. Carter disputes this, claiming there is ñnothing specifically feminineò about the features of the masks at all. ${ }^{36}$ Regardless of whether the masks are meant to depict masculine or feminine features, how much does that really say about the ritual contexts of the masks or the gender of the wearer?

The cult of Artemis Orthia primarily reflected the Spartan communityô investment in the next generation; it was for guiding the youths, both male and female, to adulthood. Another purpose of the cult of Artemis Orthia in Sparta, perhaps contrary to the image of chaste Artemis in Athenian myth, was the fertility of men and women. In order to promote fertility, Spartan girls would reportedly perform bawdy dances wearing masks and phalli, according to Pollux the orator. ${ }^{37}$ Dickens had Hesychiosôreport of Spartan men wearing female masks in mind when he studied the masks, but the accounts are not necessarily contradictory. ${ }^{38}$ If they refer to the same rituals, Pomeroy suggests that both Spartan men and women could have been cross-dressing during the performance. ${ }^{39}$ The masks do not necessarily prove that women were primarily the ones wearing them, but it is certainly short sighted to discount the possibility based on one account.

Many new avenues of thought to consider open when we explore an archaeological site with a gender-based theoretical framework. It reveals subtle biases like the assumption that the default state of being is male or subjective notions of what constitutes a ñmasculineò or ñfeminineò object. This sort of framework can also bring seemingly contradictory elements, like Artemis and domesticity, closer together. Finally, it can give us some insight into the purposes of these sites and the variety of people they would have served. Instead of pigeonholing archaeological sites and artefacts into literary illustrations, we should use literature as a guideline. By keeping the context of the ancient literature, archaeological evidence and scholarly discourse in mind, we can begin to consider women and other so-called ñspecial-interest groupsò as part of the bigger picture.

\footnotetext{
${ }^{35}$ Pomeroy, Spartan Women, 107.

${ }^{36}$ Carter, ñThe Masks of Ortheia,ò 356. She also states ñan individual may simply have held the mask in front of his face,ò implying that the wearers were male by default.

${ }^{37}$ Pomeroy, Spartan Women, 108.

${ }^{38}$ Carter, ñThe Masks of Ortheia,ò 356.

${ }^{39}$ Pomeroy, Spartan Women, 108.
} 


\section{Bibliography}

Bevan, Elinor. "The Goddess Artemis, and the Dedication of Bears in Sanctuaries." The Annual of the British School at Athens. (1987): 17-21.

Boardman, John. "Artemis Orthia and Chronology." The Annual of the British School at Athens. (1963): 1-7.

Brown, Shelby. Feminist Research in Archaeology: What Does It Mean? Why Is It Taking So Long?.Feminist Theory and the Classics. Edited by Nancy Sorkin Rabinowitz and Amy Richlin. London: Routledge, 1993.

Catling, H.W. "The Work of the British School At Athens At Sparta and in Laconia." British School at Athens Studies. (1998): 19-27.

Catling, R.W.V. "A Fragment of an Archaic Model from Artemis Orthia, Sparta." The Annual of the British School at Athens. (1994): 269-275.

Carter, Jane Burr. "The Masks of Ortheia." American Journal of Archaeology. no. 3 (1987): 355-383.

Cartledge, Paul. Sparta and Lakonia: A Regional History from 1300 to 362 BC. New York: Routledge, 2002.

Cartledge, Paul. Spartan Reflections. Berkeley and Los Angeles: University of California Press, 2001.

Cole, Susan Guettel. "Landscapes of Artemis." The Classical World. no. 5 (2000): 471481.

Hodkinson, Stephen. "Patterns of bronze dedications at Spartan sanctuaries, c. 650ð 350 BC: towards a quantified database of material and religious investment." British School at Athens Studies. (1998): 55-63.

Kopanias, Konstantinos. "Some ivories from the Geometric stratum at the sanctuary of Artemis Orthia, Sparta: interconnections between Sparta, Crete and the Orient during the late eighth century BC." British School at Athens Studies. (2009): 123-131.

Pinney, Margaret E. "Votive Gifts to Artemis Orthia." The Metropolitan Museum of Art Bulletin. no. 6 (1925): 157-159.

Pomeroy, Sarah B. Spartan Women. Oxford: Oxford University Press, 2002.

Scott, Michael. "The Rise of Women in Ancient Greece."History Today, November 2009, 34-40. 